\title{
An Analysis of Three Images in Doris Lessing's To Room Nineteen
}

\author{
Kun Zhao \\ Shandong University of Finance and Economics, China \\ Email: sjqj@163.com
}

\begin{abstract}
Doris lessing is the famous contemporary British writer and novelist. Her well-known short story To Room Nineteen tells Susan, an intelligent woman, is lost in the chaotic housework and tries to search for an authentic self which leads to her madness and ultimate suicide. This paper focuses on the three images described in Lessing's To Room Nineteen which foreshadow Susan's suicide.
\end{abstract}

Index Terms - feminine image, water image, room image

\section{INTRODUCTION OF DORIS LESSING}

Doris Lessing is a prolific and talented English writer after the World War II. As a female writer, Lessing has produced numerous works during her writing career, which cover a wide range of topics and demonstrate various styles. Readers appreciate her works so much that they praise her as one of the most wide-ranging and comprehensive of contemporary novelists, one of the most gifted of the younger group of English novelists and one of the 20th century writers by whom literary critics of the future will know us. During the past fifty years, she has been awarded a lot of influential prizes such as Somerset Maugham Award (1954), French Prix Medicis Prize (1976), W. H. Smith Literary Award (1986), Premio Internazionale Mondello (1987), Companion of Honor from the Royal Society of Literature (2001). In the year of 2007, she was awarded The Noble Prize in Literature. It was a great affirmation to her achievements in literature. The Swedish Academy praised Lessing as "that epicist of the female experience, who with skepticism, fire and visionary power has subjected a divided civilization to scrutiny". Lessing, one of the outstanding representatives of English contemporary literature, has drawn wide attention from the whole world with her impressive works. Her works have aroused general interests among critics.

Doris Lessing was born on 22 October 1919 to British parents in Kermanshah. In 1925 Lessing's family moved to a farm in what was then Southern Rhodesia (now Zimbabwe) hoping to improve their income. However, her father's farm soon went bankrupt because of his poor management, which threw the whole family into great poverty and desperation. Lessing experienced unfavorable loneliness during this period. When she ended her formal schooling because of her eye sickness at the age of fourteen, Lessing began her extensive reading of literature works at home. In the following years she worked as a young nanny, receptionist, office worker, stenographer and journalist and had several short stories published. She even used to be a member of the British Communist Party and was active in the campaign against nuclear weapons. Lessing's rich experience gives her great inspiration in writing and many of the depictions in her novels can find their trace in life in Africa. "I feel," Mrs. Lessing is quoted as saying in the interview published in The Queen in 19627 "the best thing that ever happened to me was that I was brought up out of England. I took for granted kinds of experience that would be impossible to a middle-class girl here". As a female writer, Lessing's special experience enables her to get rid of the traditional localization of the themes for most of English female writers. Full of multifarious topics and thoughts, her works are so unique and impressive that they are popular among readers in the western world.

According to Roberta Rubenstein, a Lessing critic, the whole writing career of Lessing can be divided into three main phases: breaking down and breaking out, breaking through and returning to the center. The Grass is Singing, her first novel, which was published in 1950, is the magnum opus in the first phrase and soon is widely acclaimed. The ethnic theme and psychoanalysis have aroused intensive interests in the western world. Later Lessing published her Children of Violence novel-sequence in succession, which includes Martha Quest, A Proper Marriage, A Ripple from the Storm, Landlocked and The Four-Gated City. Depicting the life exploration of a white woman who was brought up in Africa, she earns a reputation as a great realist writer. The Golden Notebook is regarded as Doris Lessing's masterpiece. The compound structure and themes have resonated among readers and won the approvals of the feminists. In the 1960s, Doris Lessing began to have an intensive interest in psychology and Sufism, which are reflected in her fictions such as Briefing for a Descent into Hell, The Summer Before the Dark, The memoirs of a Survivor and so on. Then Lessing's writing style came to a turning point and she came to focus her attention on sci-fiction., Shikasta, The Marriages Between Zones Three, Four and Five, The Sirian Experiments and The Making of the Representative for Planet 8 are well-known works in this phrase. These sci-fictions are also regarded as a reflection of the author's speculation on human history and destiny. After that, Lessing continued her writing and published her new works such as The Diaries 
of Jane Somers, The Good Terrorist, and The Fifth Child. These works are considered to have a style of realism and that is what Roberta Rubenstein calls "come back to center". All in all, Doris Lessing is cataloged as a realistic writer.

\section{INTRODUCTION OF TO ROOM NINETEEN}

To Room Nineteen was first published in A Man and Two Women, a collection of Lessing's short stories that helped her achieve her reputation as a notable short story writer. To Room Nineteen is about a middle-aged English woman, Susan, whose world in a mid-twentieth century London suburb revolved around her husband, her four children and her home. Susan and Matthew Rawlings married in their late twenties and raised four children. Everyone thought they were a perfect match who had made all the right choices in life. When the youngest child went off to school, Susan, who quit her job to mother, did not have the sense of freedom that she hopes. She felt as if she had nothing to do and never had spare moments to herself. Her time was taken up in waiting for the children to come home, consulting with the maid or preparing for dinner. She became anxious and isolated, pulling away from Mathew, and her husband began to have an affair. Finally, in order to get some time alone, she rented a hotel room every afternoon in which she just sat and embarked on a journey of self-discovery. Her husband guessed she was having an affair and tracked her down. She even created a false lover named Michael Plant to meet her husband's expectancy. Realizing that his rational world would not recognize her "irrational" feelings, she told him that she was not having an affair. The next day, she came back to the room nineteen and committed suicide.

\section{SUSAN}

Susan was an intelligent woman who did everything in an intelligent way. Susan fell in love with her present husband, Matthew, and then married him. When she became pregnant, she gave up her well-paid job, and turned herself into a full-time housewife for the sake of the four children. She even forgave her husband's unfaithfulness in marriage. "They put the thing behind them, and consciously, knowing what they were doing, moved forward into a different phase of their marriage, giving thanks for past good fortune as they did so.” (Lessing, 1980, p.987) Susan was a good wife, devoting herself to the whole family before she realized her present situation. "...because she knew, and so did he, what happened to women of fifty at the height of their energy and ability, with grown-up children who no longer needed their full devotion."(Lessing, 1980, p.987). She began thinking about herself she lost long before in her marriage life. She discovered that it was housework, children and husband that made her lose her self-identity. She could only be dependent on others, and could not rely on herself any longer. All of a sudden, she hated everything in the house, just wanted to escape from it. She thought if she could find a shelter in another place, she could be an independent person, so she finally found a room----room nineteen-----in Fred's Hotel. There she found herself again and smiling reappeared on her face. There she had no restraints and forgot everything that bothered her.

At the very beginning of the novel, the female narrator described a happy family. All the things seemed so perfect and normal. The female narrator's voice and tone sounded matter of face and understandable. However, from the narrator's calm description, we can feel an undercurrent of silent protest surging in the text. In people's eyes, they were a happy couple. Here, the happiness was something treasured by the standards of men's right society. They saved each other for the real thing. They saved each other just in the chastity. To a greater extent, it meant the need for female chastity. Presuming that Susan has sexual behavior with others before that, it was probable they would not marry. What's more, for the stable married life, Susan gave up her well-paid job. Her intelligence, for her job in the past, now had been devoted to Matthew, the children, the house and the garden.

With the female narrator's voice, we feel the confident, humorous and graceful woman, Susan, was being far away from us. She was becoming identity-losing. "The whole thing is absurd----for him to have come home to care, or for that matter not to care, is absurd... and who is Myra Jenins? Why, no one at all.” (Lessing, 1980, p.989)

But Susan gradually realized the point. "It was now, for the first time in this marriage that something happened which neither of them had foreseen." (Lessing, 1980, p.990) The double-voiced discourse correspondingly changes from the female narrator's discourse with the men's right society to the protagonist's----Susan's discourse with her husband and herself.

\section{THREE IMAGES}

\section{A. Feminine Image}

Lessing implored feminine image throughout the story symbolically which depicted women who were driven to run away from the social structures imposed by the existing patriarchal order. By describing the garden, the river, the demon, and Susan's reflection in the mirror, Lessing actually foreshadowed Susan's inevitable suicide.

Lessing revealed Susan's coming to the "end" of her innocence metaphorically, the end of her "beautiful feminine life", and then used the "slow-moving brown river" (MacGibbon \& Kee, 1963, p.2549) to foreshadow Susan's suicide, as if she was slowly breathing in death. The color white represented death and terror. Susan was terrified because she had realized that her life was "mortgaged". Lessing described Susan as a mother of four children and her life with Matthew, her husband, as a snake biting its tails. Like the number four, the story defined the ancient snake symbol, 
referred to as the representation of the eternal cycle of life, showing Lessing's constant foreshadowing of Susan's death since she felt that her life was meaningless.

Lessing described that Susan felt "as if life had become a desert" (MacGibbon \& Kee, 1963, p.2545). The constant description of this bareness was symbolic of her spiritual aridity, or of death and hopelessness. In the mirror, as she brushed her "thick healthy black hair" (MacGibbon \& Kee, 1963, p.2555), Susan saw "the reflection of a madwoman" (MacGibbon \& Kee, 1963, p.2555) and thought, "much more to the point if what looked back at her was the gingery green-eyed demon with his dry meager smile" (MacGibbon \& Kee, 1963, p.2555). Again, Lessing used symbols of color black representing death and chaos, and green representing death and decay as Susan looked at her inner "reflection" in the mirror. Lessing's use of the "demon" as a symbol of the objectification of the irrational self-Susan wished to banish from awareness. The intensity of Susan's inner struggle had placed her life in danger.

In Lessing's description, the demon represented a force directly opposite to the values conventional society imposed. For Susan, following the demon would be an act of sin, but Lessing proved that for Susan, it was better to sin than to have a lifestyle which was dictated by society. The demon represented a way out of her trapped and restricted life through the mirror. Women and mirrors were intimately linked and Susan Rawlings' voyage through looking the glass would take the traveler to the room nineteen, there to remake interiority by unmaking intelligence.

In order to escape social structures, women were sometimes driven to extremely solutions, such as committing suicide, but these solutions did not provide true freedom. The result of Susan's confining motherhood was that life became a desert for Susan; her soul was not her own. As her resentment grew she rejected the prison of motherhood for the freedom of a room of her own room nineteen in Fred's Hotel. Motherhood became a dead end for Susan Rawlings. It had become a "desert" for her, but the idea that freedom was achieved in having a "room of her own" was not consistent with the point that Lessing formulated. Susan did not achieve freedom until the end of the story when she escaped all of her "prisons" by committing suicide. Both the room and her entire existence were "prisons". Her physical escape to the hotel room was filled with emptiness and further affected her spiritual and mental health which caused her suicide.

\section{B. Water Image}

Lessing used water image in the story to show the course of the Rawlings' marriage, the emotional turmoil, and the gradual disintegration of Susan's ego which caused her lack of energy. At the beginning, Susan was satisfied with her marriage, husband and family, and was happy in the confinements of the "big married bedroom (which had an attractive view of the river)" (MacGibbon \& Kee, 1963, p.2544). Gradually, as husband and wife fell into habit and out of love, drifting apart into such different lives, they "lay side by side, or breast to breast in the big civilized bedroom overlooking the wild sullied river, and they laughed, often, for no particular reason; but they knew it was really because of these two small people, Susan and Matthew, supporting such an edifice on their intelligent love" (MacGibbon \& Kee, 1963, p.2546). The river came to symbolize Susan's reluctance to change, her inability to define herself against and in relation to the collective, rather than letting herself float along with the demoralizing collective experience. Once, to be alone, she "went to the very end of the garden by herself, and looked at the slow-moving brown river, she looked at the river and closed her eyes and breathed slow and deep, taking it into her being, into her veins"(MacGibbon \& Kee, 1963, p.2549).

Her actions here were ironic, because she identified with the social collective, although it was the very force which prevented her from having time to be herself. Gradually, however, the collective experience metaphorically submerged and subsumed Susan and she allowed herself to drown. The last time she visited the hotel she spent her time "delightfully, darkly, sweetly, letting herself slide gently, gently, to the edge of the river"(MacGibbon \& Kee, 1963, p.2564). As she died, "she was quite content lying there, listening to the dark soft hiss of the gas that poured into the room, into her lungs, into her brain, as she drifted off into the dark river"(MacGibbon \& Kee, 1963, p.2564). That final image of the mythological river of forgetfulness was significant. It illustrated Susan's complete loss self-identity to the patriarchal collective in spite of her disillusionment with its ideals. The image revealed Susan's submission to the society which was centered by the patriarchal order.

\section{Room Image}

Room nineteen was found after Susan's fourth attempt to find her own free-willed garden. She had ever set Mother's Room to escape from pressure, but she failed to get rid of the trivial chores. In Mother's Room, she would be frequently interrupted. Mother's Room soon became a valuable lesson in respect for other people's rights. It had been turned to be another family room. So "she dreamed of having a room or a place, anywhere, where she could go and sit, by herself, no one knowing where she was." (Lessing, 1980, p.970) She rented a room near Victoria. The room was ordinary and anonymous, and was just what she needed. But she was bothered by Miss Town, the owner of the hotel. She left the hotel. Susan's next escape was the wild country in Wales. She saw nothing but her devil there. So she "returned to her home and family, with the Welsh emptiness at the back of her mind like a promise of freedom." (Lessing, 1980, p.975) Finally, she escaped to room nineteen, whose owner was the kind of person who would agree everything if you gave him money. That provided Susan enough freedom in room nineteen. "The room was hideous. It had a single window, with thin green curtains, a three-quarter bed that had a cheap green satin bedspread on it, a fireplace with a gas fire and a shilling meter by it, a chest of drawers, and a green wicker armchair." (Lessing, 1980, p.980) She did nothing in room 
nineteen. But it gave her a reassuring presence. In it, she found peace and knew that it was here she belonged. "From the chair, when it had rested her, she went to the window, stretching her arms, smiling treasuring her anonymity, to look out. She was no longer Susan Rawlings, mother of four, wife of Matthew, employer of Mrs. Parkers and of Sophie Traub, with these and those relations with friends, schoolteachers, tradesman. She no longer was mistress of the big white house and garden, owning clothes suitable for this and that activity or occasion. She was Mrs. Jones, and she was alone, and she had no past and no future." (Lessing, 1980, p.981) But when she was found by her husband, and she was forced to create a lover, which drove her mad.

In To Room Nineteen, the main female character Susan, before getting married, had a well-paid job, working in an advertising firm. She had a talent for commercial drawing. She was humorous about the advertisements she was responsible for. When getting married, she did not want to base her marriage on her husband's pleasant flat, whereas whey moved to a new flat. All of these were clear proofs that Susan did not want to submit her personality and she wanted to keep her own personality. She should have lived a real happy life. However, after marriage, for the sake of the children, husband, family and intelligence, Susan was compelled to give up her job. That was the beginning of her tragedy. No job meant no money. Without money, she had to depend on her husband for money, which led to her husband's unfaithful behavior. Facing this, she even did not have the right to blame. What a shame for an intelligent woman! After taking care of her family many years and even the youngest twins had gone to school, to Susan, it seemed that it "would be the preparation for her slow emancipation away from the role of hub-of-the-family into woman-with-her-own-life." (Lessing, 1980, p.2546) However, many years of domestic seclusion and isolation from the outside contributed to her falling behind and lack of the knowledge about the real meaning of life. She did not know how to deal with her inner emptiness, which was thought as a devil by her. Especially when she was in the garden, the devil was like a stranger lurking in the garden, intending to get into Susan and taking her over. She thought of doing a part-time job, which could help her get through fast and efficiently, leaving time for her. But what kind of job? Addressing envelops? Canvassing? She was not sure. Matthew asked her: "Are you thinking of going back to work?" She answered: "No. No, not really." (Lessing, 1980, p.2555) She was puzzled, not knowing what she wanted to do and did not know what kind of job she would like to do. Unable to get rid of the emptiness at all times and not wanting to go away to a place where no one knew her and no one could disturb her. She turned into her own world, hiding from reality.

To Room Nineteen was published in 1963 when the feminist movement was in its climax. During this period, women tried hard to find their lost self, to see the world with their own eyes, to contemplate the way they led their life. From inner deep heart, Susan never gave up her longing for independence and freedom. Not very long living as a full-time housewife, she was bored with such house life and she realized she should live for the sake of something that was all the rest, and children could not be a center of life and a reason for being. This was the waking of her consciousness for freedom and independence. But under the control of the male-centered society, women, the subordinate "the other", had inevitably been stuck in an embarrassing situation of "aphasia". As the center of society, men had ruthlessly deprived women of the right to discourse, ignored their person experience. Men just wanted their wives to be typical good wives and caring mothers, who were gentle, decent and docile, and just like angels in the house. In men's eyes, those outrageous modern professional women were just devils. So did Mr. Matthew. Oppressed by the difference between real and ideal living, Susan had to escape. She wanted to keep a separate room in her own house, but she was disturbed frequently. Finally, she found a good place for her freedom------Room Nineteen. She thought this room had become more her own than the house she lived in. but still, she was detected and disturbed. Susan's struggling for freedom and independence failed. Ultimately, Susan got freedom by committing suicide and that was her way of being released from restraints of home and society. Only by this, her body and spirit can be liberated. Her sacrifice was her most crazy accusing of male-centered society. Suicide was also a kind of warning for women who were dependent on men and was overshadowed by men. Room nineteen was even a place where Susan could find her lost self, think in her own way and be happy again. It was a shelter from housework, children and unfaithful husband that obsessed with her all day and all night. Only in room nineteen could she feel she was a complete, happy and confident individual.

\section{CONCLUSION}

To Room Nineteen explored the warring impulses of intellect and instinct, mind and heart, against the backdrop of early 1960s London, when women were caught in the social conservatism of the past and unable to see the promise of a future that would encourage choice, fulfillment, and personal freedom. In this story Lessing illuminated the restrictions placed on women of that time and the tragic consequences of those restrictions. Lessing described Susan's searching for an authentic self which led to her madness and ultimate suicide by using the images analyzed in this paper.

To Room Nineteen vividly shows us the authentic and common living condition of modem women with its unique artistic charm. Susan, just like other women, suffers a lot from the male-centered society, which deprived their rights to go out to search and to receive intellectual improvement. Thus, limited in view and money, they have no real power in the outside world and no place in decision-making. They are separated from the wonders of the outside world. With the unseen chains, they are bored, restless, confused and depressed. To be angel in the house or to be devil, this is a question. Susan's experience once again shows the revolution for women against the male-centered society is a long course. 


\section{REFERENCES}

[1] Blamires, Harry. (1982). Twentieth Century English Literature. London: Macmillan Press.

[2] Bloom, Harold. (1986). Doris Lessing, New York: Chelsea House Publisher.

[3] Booth, Wayne. (1961). The Rhetoric of Fiction. Chicago: Chicago University Press.

[4] Bradbury, Malcolm. (1982).The Modern British Novel. London: Macmillan Press.

[5] Brewster, Dorothy. (1965). Doris Lessing. New York: Twayne Publishers, Inc.

[6] Fishburn, Katherine. (1985).The Unexpected Universe of Doris Lessing: A Study in Narrative Technique. Westport: Greenwood Press.

[7] Lessing, Doris. (1980) To Room Nineteen. New York: Vintage Books.

[8] Lessing, Doris. (1974). A Small Personal Voice. New York: Vintage Books.

[9] MacGibbon \& Kee, (1963). A Man and Two Women, London: University of Chicago Press.

[10] Quawas, Rula. (2007). Lessing's To Room Nineteen: Susan's voyage into the Inner Space of Elsewhere. Atlantis, 29, 107-122.

[11] Phelan, James. (2005). Living to Tell about It. Ithaca: Cornell University Press.

[12] Pruitt, Virginia. (1981). The Crucial Balance: A Theme in Lessing's Short Fiction. Studies in Short Fiction, 22, 107-110.

[13] Perkins, Wendy. (2005). Critical Essay on To Room Nineteen. Short Stories for Students, 20. 85-88.

[14] Showalter, Elaine. (2004). The Literature of Their Own-British Women Novelists from Bronte to Lessing. Princeton: Princeton University Press.

Kun Zhao, a College English teacher for non-English major students in Shandong University of Finance and Economics in Jinan, has been teaching college English for more than ten years. During this decade, she published five papers and wrote two works of American and English literature. Her research field is American and British literature. 